\title{
PARASITIC COMMUNITY OF Fransciscodoras marmoratus (REINHARDT, 1874) (PISCES: SILURIFORMES, DORADIDAE) FROM THE UPPER SÃO FRANCISCO RIVER, BRAZIL
}

\author{
SANTOS, M. D. and BRASIL-SATO, M. C. \\ Departamento de Parasitologia Animal, Universidade Federal Rural do Rio de Janeiro, \\ C. P. 74539, CEP 23851-970, Seropédica, RJ, Brazil \\ Correspondence to: Marilia de Carvalho Brasil-Sato, Departamento de Biologia Animal, \\ Universidade Federal Rural do Rio de Janeiro, C. P. 74539, CEP 23851-970, Seropédica, RJ, Brazil, \\ e-mail: mcbsato@ufrrj.br \\ Received October 1, 2004 - Accepted February 3, 2005 - Distributed August 31, 2006
}

(With 2 figures)

\begin{abstract}
One hundred and thirteen specimens of Franciscodoras marmoratus (Reinhardt, 1874) were collected in

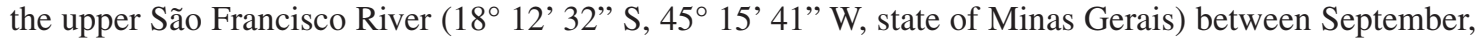
1999 and January, 2004 to investigate their parasite fauna. From this total, 45 (39.8\%) were afflicted by at least one parasite species. The parasitic richness consisted of six species represented by Hirudinea $(\mathrm{n}=20)$, Monogenoidea $(\mathrm{n}=25)$, Eucestoda $(\mathrm{n}=55)$, Nematoda $(\mathrm{n}=1, \mathrm{n}=2)$ and Acanthocephala $(\mathrm{n}=41)$ found in the dry and wet periods making a total of 144 specimens. Proteocephalus renaudi Chambrier \& Vaucher, 1994 was the only species with prevalence higher than $10 \%$ and a typical aggregate distribution pattern. The prevalence, intensity and abundance of $P$. renaudi were not influenced by the total length or sex of the hosts or by the collection periods. The relative condition factor indicated that the health of the $P$. renaudi hosts was not significantly affected in relation to fish not infected by parasites. The fish stocked in tanks before necropsy were opportunistically infested by Lernaea cyprinacea Yashuv, 1959. The various parasites found indicate that F. marmoratus is omnivorous and a potential definitive host. The parasite species, except for Acanthocephala, have expanded their known geographic distribution to the São Francisco River Basin. The parasite community was considered isolationist because of the low endoparasite diversity, infrapopulations with low intensity, lack of evidence of parasite interactions and sparse signs of parasite aggression against their hosts.
\end{abstract}

Keywords: Franciscodoras marmoratus, parasitic community, relative condition factor, freshwater fish parasites, São Francisco River.

\section{RESUMO}

\section{Comunidade parasitária de Franciscodoras marmoratus (Reinhardt, 1874), (Pisces: Siluriformes, Doradidae) do alto rio São Francisco, Brasil}

Cento e treze espécimes de Franciscodoras marmoratus (Reinhardt, 1874) foram coletados no alto São Francisco (18 $12^{\prime} 32$ ' S, 45 $15^{\circ}$ ' 41" W, Estado de Minas Gerais), entre setembro de 1999 e janeiro de 2004, para a investigação de sua parasitofauna. Desse total $45(39,8 \%)$ estavam parasitados por, pelo menos, uma espécie de parasito. A riqueza parasitária foi constituída por seis espécies representantes de Hirudinea $(n=20)$, Monogenoidea $(n=25)$, Eucestoda $(n=55)$, Nematoda $(n=1, n=2)$ e Acanthocephala $(\mathrm{n}=41)$, encontradas nos períodos da seca e da cheia, que totalizaram 144 espécimes. Proteocephalus renaudi Chambrier \& Vaucher, 1994 foi a única espécie com prevalência superior a 10\%, com típico padrão de distribuição agregado. A prevalência, intensidade e a abundância parasitária de $P$. renaudi não foram influenciadas pelo comprimento total e sexo dos hospedeiros e nem pelos períodos de coleta, respectivamente. $\mathrm{O}$ fator de condição relativo indicou que os hospedeiros de $P$. renaudi não tiveram higidez 
significativamente afetada em relação aos peixes não parasitados. Os peixes estocados em tanques, antes das necropsias, foram oportunistamente infestados por Lernaea cyprinacea Yashuv, 1959. Os diversos parasitos encontrados indicam $F$. marmoratus onívoro e potencial hospedeiro definitivo. As espécies de parasitos, com exceção de Acanthocephala, têm ampliada sua distribuição geográfica conhecida para a bacia do rio São Francisco. A comunidade parasitária foi considerada isolacionista devido à baixa diversidade endoparasitária, infrapopulações com baixa intensidade, interações parasitárias não evidentes e raros sinais de agressões dos parasitos contra seus hospedeiros.

Palavras-chave: Franciscodoras marmoratus, comunidade parasitária, fator de condição relativo, parasitos de peixes de água doce, rio São Francisco.

\section{INTRODUCTION}

The São Francisco River Basin occupies an area of $631,133 \mathrm{~km}^{2}, 7.4 \%$ of Brazilian territory (Paiva, 1982). In spite of their interest, fish parasite studies have only been done recently (Moreira et al., 1991; Brasil-Sato \& Pavanelli, 1998, 1999; Brasil-Sato, 2002; Brasil-Sato \& Santos, 2003, Santos \& Brasil-Sato, 2004).

Locally also referred to as "serrudo" or "bozó", F. marmoratus is a benthonic species and the only representative doradid in the upper São Francisco River (Britski et al., 1988). It is omnivorous (Com. pes., Dr. Yoshimi Sato), reaches $24 \mathrm{~cm}$ in length and its gonadal maturation occurs at $19 \mathrm{~cm}$ (Cardoso, 1934).

In this paper the metazoan parasite community of this host was analyzed at the component and infracommunity levels, establishing possible relationships with host biometry and food resources. The examination of fish health and parasite infection by cestodes by applying the relative condition factor $(\mathrm{kn})$ tool is also presented.

\section{MATERIALS AND METHODS}

From September, 1999 to January, 2004, 113 specimens of $F$. marmoratus were collected in a section of the upper São Francisco River, downstream from the Três Marias Dam $\left(18^{\circ} 12^{\prime} 32^{\prime \prime} \mathrm{S}\right.$, $45^{\circ} 15^{\prime} 41^{\prime \prime} \mathrm{W}$, State of Minas Gerais) by fishermen of the Estação de Hidrobiologia e Piscicultura of the Companhia de Desenvolvimento dos Vales do São Francisco e Parnaíba (EPT/CODEVASF) using gill netting. The collection periods were analyzed according to the mean seasons of the upper São Francisco: the dry season includes the colder months (May-October) and the wet season the hotter months (November-April). The fish were identified according to Britski et al. (1988). Out of the total fish collected, some were immediately necropsied in the Laboratório de Ictiologia of the EPT/CODEVASF, others were stocked in tanks where some specimens were attacked by ectoparasites and the rest were carried to the LaboratóriodeIctioparasitologiaof theUniversidade Federal Rural do Rio de Janeiro. There, the fish were maintained in an aquarium until necropsied. The male $(\mathrm{n}=47)$ averaged $18.5 \pm 4.2 \mathrm{~cm}(10$ to $32 \mathrm{~cm})$ in total length and $81.7 \pm 70.7 \mathrm{~g}(12$ to $520 \mathrm{~g})$ in weight and the female $(\mathrm{n}=66)$ averaged $21.0 \pm 5.0 \mathrm{~cm}(12$ to $36 \mathrm{~cm})$ and $129.6 \pm 124.4 \mathrm{~g}$ (12 to $688 \mathrm{~g}$ ) making a total of 113 specimens. Voucher specimens of F. marmoratus were deposited in the Museu de Zoologia of the Universidade de São Paulo, São Paulo, Brazil (MZUSP: 84224).

Specimens of Copepoda, Hirudinea, Monogenoidea, Eucestoda, Nematoda and Acanthocephala were collected, fixed and processed according to Amato et al. (1991) and Eiras et al. (2000). Parasites were identified according to Kabata (1979) (Copepoda); Pennak (1989) (Hirudinea); Kritsky et al. (1986) and Boeger \& Kritsky (1993) (Monogenoidea); Rego et al. (1999) (Eucestoda); Vaz \& Pereira (1934), Chabaud (1974), Thatcher \& Padilha (1977) and Vicente et al. (1985) (Nematoda); Brasil-Sato \& Pavanelli (1998) (Acanthocephala). The statistical analysis was only carried out for the cestode species whose prevalence was higher than $10 \%$, in accordance with Bush et al. (1990). Ecological terminology followed Bush et al. (1997). The Student's $t$ test was used to evaluate the total length, weight, intensity and parasitic abundance between male and female hosts and evaluate the parasitic abundance in relation to the collection periods of the hosts; the $G$ log-likelihood test with 
$2 \times 2$ contingency table was used to evaluate the prevalence of the parasites in relation to the sex of the hosts; Spearman's rank correlation coefficient, $r_{\mathrm{s}}$, was used to calculate possible correlations between the total length of the hosts and the parasitic intensity; Pearson's coefficient correlation, $r$, was used to indicate the relationship between the total length of the hosts and the prevalence of parasites, with previous transformation of these data (Zar, 1996) and partition of host samples into intervals calculated by Sturges' formula (Sturges, 1926); the Mann-Whitney test, $U$, was used to evaluate the parasitic intensity in relation to the collection period; the index of dispersion (quotient between variance and mean of parasite abundance) and $d$ test were used to determinate distribution patterns (Ludwig \& Reynolds, 1988). The dominance frequency, the frequency of shared dominance and the relative dominance of each parasite species were calculated according to Rohde et al. (1995). The parasitic diversity, maximum diversity and equitability of the parasites species from the community were calculated through the ShannonWeaner $\left(H^{\prime}\right)$ following Serra-Freire (2002). To evaluate possible differences in the health of nonparasited fish and those infected by cestodes, the relative condition factor - Kn (Le Cren, 1951) was applied. The statistical analysis followed Zar
(1996). The statistical significance for all tests was $P<0.05$. Voucher specimens of helminths, hirudineans and copepods were deposited in the Coleção Helmintológica do Instituto Oswaldo Cruz (CHIOC), Rio de Janeiro, Brazil.

\section{RESULTS}

\section{Component community}

Six species of metazoan parasites were found: an undetermined Hirudinea species $(\mathrm{n}=20)$, a monogenoid Vancleaveus cicinnus Kritsky et al., 1986 ( $\mathrm{n}=25)$, a cestode Proteocephalus renaudi Chambrier \& Vaucher, $1994(\mathrm{n}=55)$, two nematodes Porrocaecum sp. $(\mathrm{n}=2)$ and Spinitectus sternopigy Petter, $1984(\mathrm{n}=1)$ and an acanthocephalan Neoechinorhynchus pimelodi Brasil-Sato \& Pavanelli, $1998(n=41)$ making a total of 144 specimens. Proteocephalus renaudi was the dominant species and the only one with prevalence higher than $10 \%$ (Table 1), with a frequency of dominance 16 , frequency of shared dominance three and relative dominance average $0.81 \pm 0.31$. Proteocephalus renaudi showed the typical aggregate pattern of distribution (ID $=3.45$; $d=13$ ). The mean parasite species diversity was low $\left(H^{\prime}=2.06\right)$ and the maximum diversity was

TABLE 1

Prevalence, intensity, mean intensity, mean abundance and site of infection/infestation of the metazoan parasites of Franciscodoras marmoratus (Reinhardt, 1874) from the upper São Francisco river, Três Marias, Brazil.

\begin{tabular}{|c|c|c|c|c|c|}
\hline Parasites & Prevalence $(\%)$ & Intensity & Mean intensity & Mean abundance & Site \\
\hline \multicolumn{6}{|l|}{ HIRUDINEA } \\
\hline $\begin{array}{l}\text { Glossiphonid undetermined } \\
\text { CHIOC } 35285\end{array}$ & 8.0 & $1-7$ & $2.2 \pm 1.9$ & $0.2 \pm 0.8$ & Gills \\
\hline \multicolumn{6}{|l|}{ MONOGENOIDEA } \\
\hline $\begin{array}{l}\text { Vancleaveus cicinnus } \\
\text { CHIOC } 36405\end{array}$ & 8.0 & $1-5$ & $2.8 \pm 1.7$ & $0.2 \pm 0.8$ & Gills \\
\hline \multicolumn{6}{|l|}{ EUCESTODA } \\
\hline $\begin{array}{l}\text { Proteocephalus renaudi } \\
\text { CHIOC } 36403 \mathrm{a}, \mathrm{b} \\
\text { CHIOC } 36407 \mathrm{a}, \mathrm{b} \\
\end{array}$ & 20.3 & $1-6$ & $2.4 \pm 1.7$ & $0.5 \pm 1.2$ & $\begin{array}{l}\text { Middle and } \\
\text { anterior gut }\end{array}$ \\
\hline \multicolumn{6}{|l|}{ NEMATODA } \\
\hline $\begin{array}{l}\text { Porrocaecum sp. (larvas) } \\
\text { CHIOC } 36404 \\
\text { Spinitectus sternopygi }\end{array}$ & $\begin{array}{l}1.8 \\
0.9\end{array}$ & - & $\begin{array}{l}1 \\
1\end{array}$ & $\begin{array}{l}<0.1 \\
<0.1\end{array}$ & $\begin{array}{l}\text { Celomatic } \\
\text { cavity }\end{array}$ \\
\hline \multicolumn{6}{|l|}{ ACANTHOCEPHALA } \\
\hline Neoechinorhynchus pimelodi & 8.0 & $1-15$ & $4.5 \pm 4.6$ & $0.4 \pm 1.7$ & Anterior gut \\
\hline
\end{tabular}


2.58. The equitability (0.79) indicates a tendency to equilibrium in the parasite species abundance. Franciscodoras marmoratus constitutes a new register for all the parasites found. The São Francisco Basin enlarges the known distribution of the parasites except for the acanthocephalan species.

\section{Infracommunities}

From the total fish examined (113), $45(39.8 \%)$ were parasited by at least one parasite species. The parasitic richness was made up of six species in the dry and wet periods. Thirty nine hosts $(34.5 \%)$ showed infection/infestation with one parasite species, four $(3.5 \%)$ with two species and two (1.8\%) with three species (Table 2).

The statistical analysis showed a significant difference in the total length $(t=-2.66 ; P=0.008)$ and weight $(t=-2.38 ; P=0.02)$ between the male and female hosts. The prevalence of $P$. renaudi did not differ significantly between male and female hosts $(G=0.14,0.10<P<0.25)$. The prevalence of $P$. renaudi did not differ among the host length intervals $(r=0.05 ; P=0.89)$. The intensity and parasitic abundance of $P$. renaudi did not differ between male and female hosts $(t=0.30, P=0.76$; $t=0.37, P=0.71$, respectively). The intensity and parasitic abundance of $P$. renaudi were not correlated with the total body length $(r=-0.16, P=0.47$; $r_{\mathrm{s}}=0.15, P=0.12$, respectively). The prevalence, intensity and parasitic abundance of $P$. renaudi were not influenced by the collection periods $(G=2.16,0.10<P<0.22 ; U=1175 ; P=0.22$; $t=1.12, P=0.27$, respectively). The relative condition factor of fish parasited by $P$. renaudi did not differ significantly in relation to those free of parasites $(t=0.63 P=0.53)$ (Fig. 1 and 2).

Among the twenty two fish stocked in tanks before the necropsies, fifteen were infested by Lernaea cyprinacea Yashuv, 1959. From these, eleven were infested by copepodits, three by adults and one by one copepodit and by adults. The prevalence of $L$. cyprinacea was not correlated between male and female hosts $(G=1.5, P>0.05)$. The prevalence of $L$. cyprinacea was not correlated to the hosts' length intervals ( $r=0.38, P=0.52$ ). The intensity and parasitic abundance did not differ between the male and female hosts $(t=0.01$, $P=0.99 ; t=0.44, P=0.78$, respectively). The parasitic intensity was not correlated with the total host length $\left(r_{\mathrm{s}}=0.17, P=0.54\right)$, unlike the parasitic abundance $\left(r_{\mathrm{s}}=0.61, P=0.003\right)$.

\section{DISCUSSION}

The parasitic richness was established for two species of ectoparasites and four species of endoparasites, three of them mature and one larval, suggesting that $F$. marmoratus is a definitive host in this limnic system. The results obtained in this work show that endoparasites are dominant in the parasite community of this host. The female specimens of $F$. marmoratus were larger (total

TABLE 2

Parasitism patterns of Franciscodoras marmoratus (Reinhardt, 1874) in relation to the number of parasited hosts.

\begin{tabular}{|l|c|}
\hline \multicolumn{1}{|c|}{ Parasitism patterns } & Number of parasited hosts \\
\hline Single infection/infestation & 19 \\
\hline Proteocephalus renaudi & 7 \\
\hline Neoechinorhynchus pimelodi & 6 \\
\hline Glossiphonid undetermined & 6 \\
\hline Vancleaveus cicinnus & 1 \\
\hline Porrocaecum sp. & 2 \\
\hline Multiple infection/infestation & 1 \\
\hline Glossiphonid + P. renaudi & 1 \\
\hline Vancleaveus cicinnus + P. renaudi & 1 \\
\hline Porrocaecum sp. + N. pimelodi & 1 \\
\hline Glossiphonid + V. cicinnus + P. renaudi & \\
\hline Spinitectus sternopygi + N. pimelodi + V. cicinnus & \\
\hline
\end{tabular}




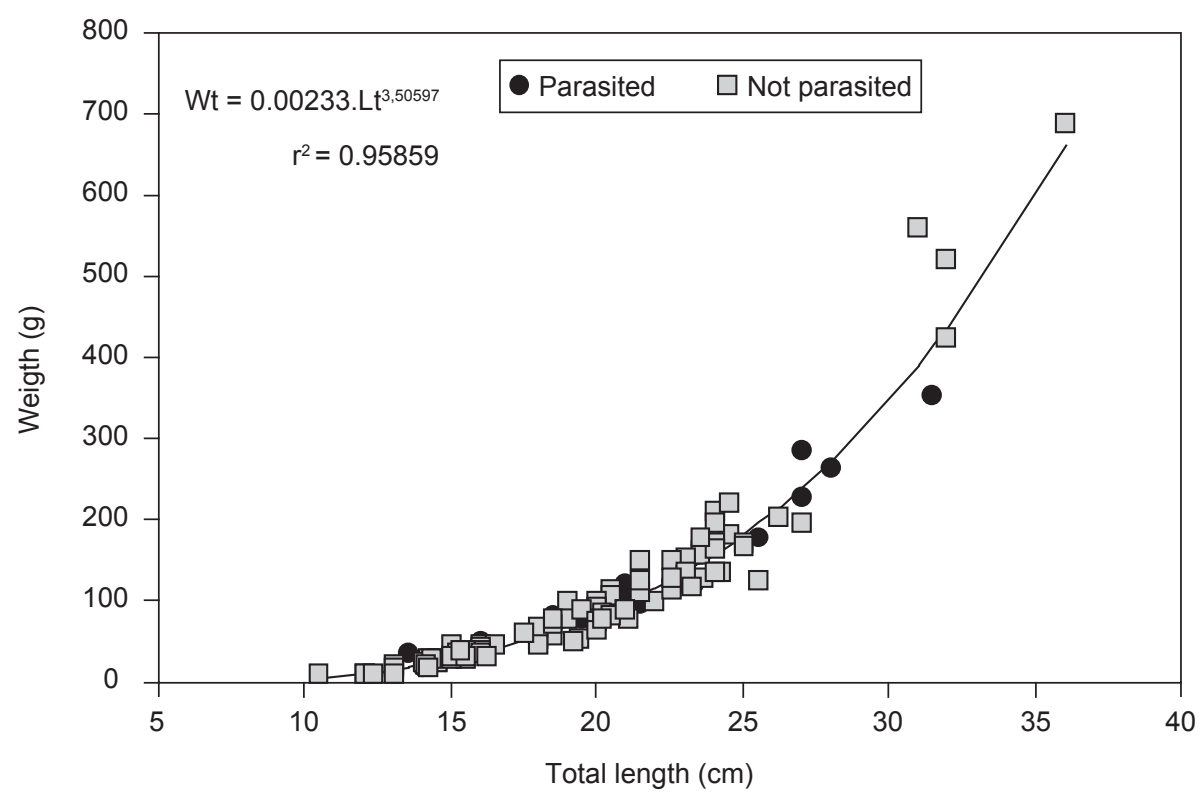

Fig. 1 - Relationship length total-weight of Franciscodoras marmoratus (Reinhardt, 1874), parasited by Proteocephalus renaudi and not parasited, collected between September, 1999 and January, 2004, from the upper São Francisco River, downstream Três Marias Dam, Minas Gerais.

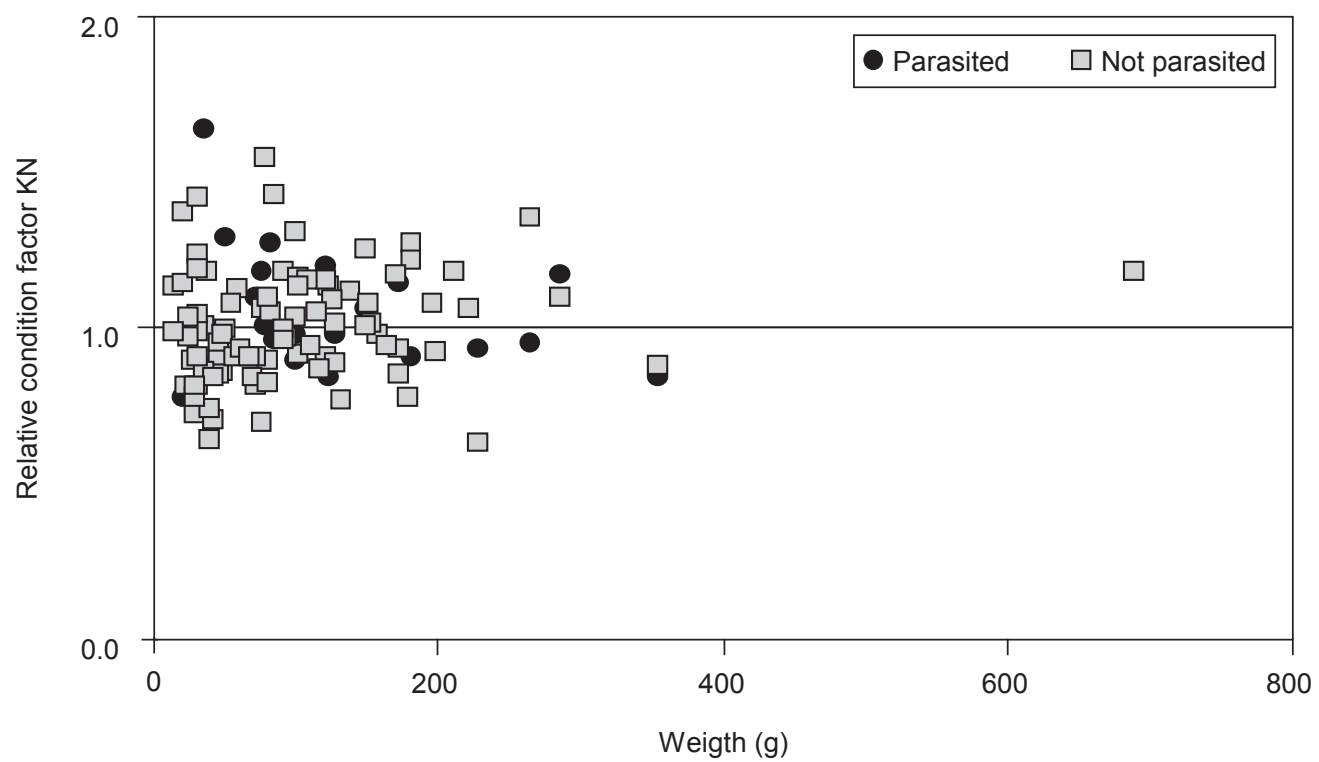

Fig. 2 - Variation of the relative condition factor $(\mathrm{Kn})$ around the standard value $(\mathrm{Kn}=1)$ in relation to the weight of Franciscodoras marmoratus (Reinhardt, 1874) (parasited by Proteocephalus renaudi and not parasited), collected between September, 1999 and January, 2004 from the upper São Francisco River, downstream Três Marias Dam, Minas Gerais.

length) and heavier than the male (significant negative correlation), which is a pattern for most of the fish species in the São Francisco River Basin (Sato et al., 1996, Soares et al., 1996, Ricardo et al., 1998, Sato et al., 1999, Sato \& Godinho, 2003). Despite the biometric differences among hosts, sex was not found to be an influence in the parasite infrapopulations. 
Increased prevalence and intensity of parasitism with host age, qualitative changes in the ecology of the host with age and initial infestation by ectoparasites in smaller fish or by parasites that actively penetrate the host are the norms for the parasitofauna of freshwater fish (Dogiel, 1961). Despite these principles, in the parasite community of $F$. marmoratus, size was not an influence, since both young and adult fish had the same parasites (ecto and endoparasites), probably in the case of endoparasites because the host maintains the same diet at different ages. Omnivorism including intermediate arthropod hosts favored the installation of endoparasites and guaranteed infection in fish of different sizes (Santos \& Brasil-Sato, 2004). It is probable that omnivorism has favored predation of intermediate hosts such as copepods among other arthropods, generating a greater number of $P$. renaudi in F. marmoratus. Arthropods are likely common prey in the diet of $F$. marmoratus, which are probably intermediate hosts of the cestodes, nematodes and acanthocephalans. These results indicate the need for studies to elucidate the biological cycles of freshwater fish parasites, mainly in continental tropical water bodies. In the case of $P$. renaudi, the predation of intermediate hosts was not influenced by the two collection periods (dry and wet season). Probably these organisms are present the whole year round in this water system, hence favoring the development cycle of this proteocephalid.

Despite the swimming movements of the bentonic host and the monoxene cycle of the Monogenoidea, the prevalence of $V$. cicinnus in F. marmoratus (new host) was less than ten percent. The description and records of the occurrence of the species Vancleaveus Kritsky et al., 1986 in doradid and pimelodid fish distributed in the Paraná-Plata and Amazon basins (Kritsky et al., 1986, Suriano \& Incorvaia, 1995), combined with the low quantities of $V$. cicinnus in F. marmoratus, show that in the São Francisco basin (new locality) this parasite can occur in other fish species.

The fish that were stocked in tanks before being necropsied were infested by copepodits and adults of L. cyprinacea. This infestation probably came from contaminated tanks. The parasite prevalence and abundance were higher in the greater fish. The higher infestation must be related to the greater surface area on which these parasites can become established in the confined hosts. Although in the present study, the infestation was caused by being kept in tanks, there is a possibility that these copepods were already infesting native fish in Brazilian rivers, due to massive escapes from fish farms to natural environments, which can enable or facilitate the dissemination of parasites to the rivers (Gabrielli \& Orsi, 2000). Hence, there is a need for adequate handling to avoid this type of contamination.

In the literature on fish parasites there is little information regarding methods to evaluate to what extent host populations are compromised by parasites. In general, the existing studies have been based on observations of mortality or apparent lesions caused by parasites (Martins \& Romero, 1996; Ostrensky \& Boeger, 1998; Pavanelli et al., 1998, 2000). In F. marmoratus, there was no significant difference in the relative condition factor between fish free of parasites and those infected by $P$. renaudi. It is possible that in confinement, analysis of the relative condition factor, as proposed by Le Cren (1951), is a useful methodology to detect the species of parasites that affect the health of fish.

The typical aggregate standard distribution encountered for $P$. renaudi in the host is common among endoparasites and can be justified by the type of distribution of intermediate hosts, by the spatial dispersion (in this case, the mobile phase of the intermediate host) of the infectious stages and the rare evidence of the host reaction to parasitism (Kennedy, 1976; Anderson \& Gordon, 1982).

Considering that $F$. marmoratus is omnivorous, the diversity and richness of parasites found were low in relation to that recorded by Brasil-Sato (1999) for the parasitic communities of $P$. maculatus La Cepède, 1803, an omnivorous fish of the São Francisco and Paraná rivers, in which high diversity and richness were registered $\left(H^{\prime}=3.37\right.$ and 25 parasite species and $H^{\prime}=3.36$ and 31 parasite species, respectively). According to Bell \& Burt (1991), the diversity may be related to the size, longevity, host diet and type of the environment. Considering that $F$. marmoratus showed little variation in diet at different sizes (the same species of parasites in fish of different sizes and most prevalent parasite species not related to host sex or size) and that the host collection region in question was the same, it is possible 
that the differences in the parasite communities among the omnivorous fish is due to the restricted diet items of F. marmoratus. The low diversity, infrapopulations of reduced intensity, nonsignificant scarce interspecies relations, species with low prevalence and rare reactions of the hosts to parasite aggressions characterize the community of F. marmoratus as isolationist. Although apparently insaturated, the parasite community of $F$. marmoratus reflected its restricted feeding habits, leading to low endoparasitic diversity and richness.

Acknowledgments - We are very grateful to Dr. Yoshimi Sato (EPT/CODEVASF) for the resources and scientific information available about the host and to Convênio CEMIG-CODEVASF for providing logistical support. This research was funded by Conselho Nacional de Desenvolvimento Científico e Tecnológico (CNPq).

\section{REFERENCES}

AMATO, J. F. R., BOEGER, W. A. \& AMATO, S. B., 1991, Protocolos para laboratório coleta e processamento de parasitos do pescado. Imprensa Universitária, Seropédica, Universidade Federal Rural do Rio de Janeiro, 81p.

ANDERSON, R. M. \& GORDON, D. M., 1982, Process influencing the distribution of parasite numbers within hosts populations with special emphasis on parasite-induced host mortalities. Parasitology, 85: 373-398.

BELL, G. \& BURT, A., 1991, The comparative biology of parasite species diversity: internal helminthes of freshwater fishes. J. Anim. Ecol., 60: 1047-1063.

BOEGER, W. A. \& KRITSKY, D. C., 1993, Phylogeny and a revised classification of the Monogenoidea Bychowsky, 1937 (Platyhelminthes). Syst. Parasitol., 26: 1-32.

BRASIL-SATO, M. C., 1999, Ecologia das comunidades de parasitos metazoários de Pimelodus maculatus Lacépède, 1803 (Siluroidei: Pimelodidae) das bacias do rio São Francisco, Três Marias, MG e do rio Paraná, Porto Rico, $P R$.. Tese de Doutorado, Universidade Federal de São Carlos, São Carlos, SP, 255p.

BRASIL-SATO, M. C., 2002, Digenea of Salminus brasiliensis (Cuvier, 1817) (Osteichthyes, Characidae) of the São Francisco river basin, Brazil. Rev. Brasil. Parasitol. Vet., 11: 95-98.

BRASIL-SATO, M. C. \& PAVANELLI, G. C., 1998, Neoechinorhynchus pimelodi sp. n. (Eoacanthocephala: Neoechinorhynchidae) de Pimelodus maculatus Lacépède, 1803, da bacia do rio São Francisco, Três Marias, Minas Gerais, Brasil. Rev. Brasil. Zool., 15: 1003-1011.

BRASIL-SATO, M. C. \& PAVANELLI, G. C., 1999, Ecological and reproductive aspects of Neoechinorhynchus pimelodi Brasil-Sato \& Pavanelli, 1997 (Eoacanthocephala: Neoechinorhynchidae) of Pimelodus maculatus Lácèpede, 1803 (Siluroidei: Pimelodidae) of the São Francisco river, Três Marias, MG, Brazil. Rev. Brasil. Zool., 16: 73-82.
BRASIL-SATO, M. C. \& SANTOS, M. D., 2003, Helmintos de Myleus micans (Lütken, 1875) (Characiformes: Serrasalminae) do Rio São Francisco, Brasil. Rev. Brasil. Parasitol. Vet., 12: 131-134.

BRITSKI, H. A., SATO, Y. \& ROSA, A. B. S., 1988, Manual de identificação de peixes da região de Três Marias (com chaves de identificação para os peixes da Bacia do São Francisco). $3^{\mathrm{a}}$ ed., CODEVASF, Brasília, 115p.

BUSH, A. O., AHO, J. M. \& KENNEDY, C. R., 1990, Ecological versus phylogenetic determinants of helminth parasite community richness. Evol. Ecol., 4: 1-20.

BUSH, A. O., LAFFERTY, K. D., LOTZ, J. M. \& SHOSTAK, A. W., 1997, Parasitology meets Ecology on its own terms: Margolis et al. Revisited. J. Parasitol., 83: 575-583.

CARDOSO, D. M., 1934, Relação gênito-hipofisária e reprodução de peixes. Arq. Ins. Biol., 5: 133-136.

CHABAUD, A. G., 1974, Keys to general of the order Spirurida. N $N^{\text {3 }}$, Part 2. Spiruroroidea, Habronematoidea and Acuaroidea. In: A. G. Chabaud (ed.), CIH Keys to the nematode parasites of vertebrates. $\mathrm{CAB}$, Farnham Royal, Bueks, England, pp. 29-50.

DOGIEL, V. A., 1961, Ecology of the parasites of freshwater fishes. In: Dogiel, V. A., Petrushevski, G. K. \& Polyanski, Yu. I (eds), Parasitology of fishes. London, Oliver \& Boyd, $47 \mathrm{p}$.

EIRAS, J. C., TAKEMOTO, R. M. \& PAVANELli, G. C., 2000, Métodos de estudo e técnicas laboratoriais em parasitologia de peixes. EDUEM, Maringá, 171p.

GABRIELLI, M. A. \& ORSI, M. L., 2000, Dispersão de Lernaea cyprinacea (Linnaeus) (Crustacea, Copepoda) na região norte do estado do Paraná, Brasil. Rev. Brasil. Zool., 17: 395-399.

KABATA, Z., 1979, Parasitic Copepoda of British Fishes. The Ray Society, London, 468p.

KENNEDY, C. R., 1976, Reproduction and dispersal. pp. 143160. In: C. R. Kennedy (ed.), Ecological Aspects of Parasitology. NorthoHolland Publishing Company, Amsterdam.

KRITSKY, D. C., THATCHER, V. \& BOEGER, W. A., 1986, Neotropical Monogenea. 8. Revision of Urocleidoides (Dactylogyridae, Ancyrocephalinae). Proc. Helminthol. Soc. Wash., 53: 1-37.

LE CREN, E. D., 1951, The length-weight relationship and seasonal cycle in gonad weight and condition in the perch Perca fluviatilis. J. Anim. Ecol., 20: 201-219.

LUDWIG, J. A. \& REYNOLDS, J. F., 1988, Statistical Ecology: a primer on methods and computing. Wiley-Interscience Publications, New York, 377p.

MARTINS, M. L. \& ROMERO, N. G., 1996, Efectos del parasitismo sobre el tejido branquial em peces cultivados: estúdio parasitológico e histopatologico. Rev. Brasil. Zool., 13: 489-500.

MOREIRA, N. I. B., OLIVEIRA, C. L. \& COSTA, H. M., 1991, A new helminth parasite of fish: Spirocamallanus freitasi sp. n. (Nematoda - Camallanidae). Mem. Inst. Oswaldo Cruz, 86: 429-431. 
OSTRENSKY, A. \& BOEGER, W., 1998, Piscicultura: fundamentos e técnicas de manejo. Guaíba, Agropecuária, 211p.

PAIVA, M. P., 1982, Grandes represas do Brasil. Editerra, Brasília, 304p.

PAVANELLI, G. C., EIRAS, J. C. \& TAKEMOTO, R. M., 1998, Doenças de peixes. Profilaxia, Diagnóstico e Tratamento. EDUEM, Maringá, 264p.

PAVANELLI, G. C., TAKEMOTO, R. M. \& EIRAS, J. C., 2000, Sanidade de peixes; aqüicultura empresarial: pesquisa e planejamento. Informe Agropecuário, 21: 48-52.

PENNAK, R. W., 1989, Fresh-water Invertebrates of the United States. Protozoa to Mollusca. Wiley-Interscience Publications, New York, 628p.

REGO, A. A., CHUBB, J. C. \& PAVANELLI, G. C., 1999, Cestodes in South American freshwater teleost fishes: keys to genera and brief description of species. Rev. Brasil. Zool., 16: 299-367.

RICARDO, M. C. P., SATO, Y., BAZZOLI, N. \& RIZZO, E., 1998, Análise histológica da reprodução de Tetragonopterus chalceus Agassiz, 1829 (Pisces, Characidae) na represa de Três Marias, Minas Gerais. Bios, 6: 113-120.

ROHDE, K., HAYWARD, C. \& HEAP, M., 1995, Aspects of the ecology of metazoan ectoparasites of marine fishes. Intern. J. Parasitol., 25: 945-970.

SANTOS, M. D. \& BRASIL-SATO, M. C., 2004, Parasitos metazoários de Franciscodoras marmoratus (Reinhardt, 1874), "serrudo" (Siluriformes: Doradidae) do rio São Francisco, Brasil. Rev. Brasil. Parasitol. Vet., 13: 18-22.

SATO, Y., CARDOSO, E. L., GODINHO, A. L. \& GODINHO, H. P., 1996, Hypophysation of fish Prochilodus affinis from the Rio São Francisco basin, Brazil. Arq. Bras. Med. Vet. Zootec., 48(Suplemento 1): 55-62.

SATO, Y., FENERICH-VERANI, N., VERANI, J. R., GODINHO, H. P. \& SAMPAIO, E. V., 1999, Reproductive aspects of the yellow-mandi catfish Pimelodus maculatus Lacépède, 1803 (Osteichthyes, Siluriformes). Rev. Brasil. Zool., 16: 981-986.

SATO, Y. \& GODINHO, H. P., 2003, Migratory fishes of the São Francisco river. pp. 195-232. In: J. Carolsfeld, B. Harvey, C. Ross, A. Baer (ed.), Migratory fishes of South America: biology, fisheries and conservation status. World Fisheries Trust, International Development Research Centre and World Bank, Victoria.

SERRA-FREIRE, N. M., 2002, Planejamento e Análise de Pesquisas Parasitológicas. Editora da Universidade Federal Fluminense, Niterói, 199p.

SOARES, M. G., DABÉS, A. C., SATO, Y., BAZZOLI, N., RIZZO, E. \& FERREIRA, R. M. A., 1996, Tamanho de primeira maturação sexual do Schizodon knerii e do Leporinus piau (Teleostei, Anostomidae) na represa de Três Marias, MG. Arq. Bras. Med. Vet. Zootec., 48(Suplemento 1): 47-54.

STURGES, H. A., 1926, The choice of a class interval. J.l Am. Stat., 21: 65-66.

SURIANO, D. M. \& INCORVAIA, I. S., 1995, Ancyrocephalid (Monogenea) parasites from siluriform fishes from the Paranean-Platean ichthyogeographical province in Argentina. Acta Parasitol., 40: 113-124.

THATCHER, V. E. \& PADILHA, T. N., 1977, Spinitectus jamundensis sp.n. (Nematoda, Spiruroidea) from a colombian freshwater fish, Prochilodus reticulatus Steind. Rev. Brasil. Biol., 37: 799-801.

VAZ, Z. \& PEREIRA, C., 1934, Contribuição dos nematóides de peixes fluviais do Brasil. Arq. Inst. Biol., 5: 87-103.

VICENTE, J. J., RODRIGUES, H. O. \& GOMES, D. C., 1985, Nematóides do Brasil. $1^{\text {a }}$ parte: Nematóides de peixes. Atas Soc. Biol. Rio J., 25: 1-75.

ZAR, J. H., 1996, Biostatistical Analysis. Prentice Hall, New Jersey, 662p. 